Marcel Courthiade

Inalco

Paris-City Sorbonne
UDC 371.3::811.163.6'243(450.361)

DOI https://doi.org/10.18485/fid.2017.7.ch29

\title{
THE EMERGENCE OF A PROJECT OF LANGUAGE STANDARDIZATION FOR RROMANI IN SFR YUGOSLAVIA AND THE USSR
}

У раду се извештава о томе како је настао заједнички ромски правопис пре пола века на територији Јужне Србије у СФРЈ, када су млади Роми почели да пишу поезију под утицајем других мањина и федералног система вишејезичности. У овом контексту, један ромски песник из Лесковца, Исмет Јашаревић, покушао је да пише наизменично на варијететима свог оца и мајке, али је приметио да, иако је постојало савршено узајамно разумевање у усменој комуникацији међу говорницима ова два варијетета, ово разумевање је нестајало чим су ти варијетети били записани. Стога, он је покушао да пронађе заједнички начин писања за оба варијетета. Дакле, питање правописа који покрива варијетете постављено је, уз неколико покушаја, углавном у његовим делима, али и у Рашити и Гаши стиховима. Решење које је, пре свега, сковано тамо, проширено је на ширу област, укључујући Федералну Државу Македонију, а затим успешно прилагођено за више народних варијетета. У исто време, постојао је сличан покушај проналажења заједничког правописа у СССР, на иницијативу Лексе Мануша, који је осмислио буквар у Москви. На југословенском нивоу, такође је објављен буквар у Сарајеву у оквиру издавачке куће Свјетлост и књига "Рромани фонетика тхај лекхипа“" штампана у Новом Саду за црногорску издавачку кућу Побједа (обе 1986. године). У раду такође има речи о улози коју је одиграло истраживање око издања стваралаштва младих у одговарању на питања о - тад још увек неутврђеном - јединству ромског језика, уз помоћ дијалектометричке методе. Године 1990. Четврти конгрес Рома усвојио је одлуку о функционисању стандардног ромског алфабета, који је убрзо након тога ступио на снагу у румунским школама - са укупно 500.000 ромских ученика који су од тада имали користи од часова матерњег језика и културе. Међутим, услед делимичне изолације, као последице међународне блокаде Југосалвије, и делимично због унутрашњих сукоба необразованих учесника, који су се нашли на позицијама кључних актера, као и разних потоњих манипулација, заједнички ромски правопис још увек је блокиран у Србији од стране присталица ћирилице и хрватске латинице, иако су оба писма веома далеко од карактеристика ромског и њихова употреба би одсекла српске Роме од европске ромске заједнице у погледу писања, издаваштва и информационих технологија - односно у већини медија. Још увек је исувише рано да се каже да ли је ово добро осмишљен план масивног (и расистичког) језичког уништења или је само резултат неспособности органа власти. 
Кључне речи: настава ромског језика, ромски књижевни стандард, историја стандардизације, ромски у СФРЈ, ромски у СССР, ромски у Румунији, усмена/писана комуникација.

We all get the impression that the times when people used to ask themselves whether there was only one Rromani language or several such languages, belong to prehistory: in fact when in the 1960s the Atlas Linguarum Europece collected the Rromani samples for its dialectal map of Europe, the researchers threw into one single bag genuine Rromani vernaculars, in the exact sense of the word, together with some varieties used in Spain and England, which belong more to the categories of Spanish or English slangs with several dozen inserted Rromani words, than to Rromani itself. Prof. Dalibor Brozović from Zadar wrote quite appropriately about this in the Proceedings of Sarajevo.

Clearly enough, in such a state of ignorance, it was not possible to talk about any standardization, because it was not even clear what one was supposed to standardize.

Now we know that there is only one Rromani language, divided into two super-dialects - the legacy of more or less $90 \%$ of all the Rroms on Earth. In addition there are several varieties, which we have already mentioned, representing the legacy of some $10 \%$ of the Rroms, primarily in Spain, England, Northern Hungary and in Brazil.

How did we progress from a deep ignorance to a more or less clear picture of the dialectical structure of the Rromani language?

\section{First steps}

The engine of this progress was primarily the desire to create a common standard language for all the Rroms of the world, a desire which appeared more or less simultaneously in the 70s in the territories of Yugoslavia and the Soviet Union, due to the fact that in these countries, the standardization of other minority languages and the development of their literature gave Rroms an example inspiring them to follow the same path. In fact, the idea and method of standardization of Rromani had already come briefly in the introduction to the grammar of the dialect of the Rroms of Slovakia, from the pen of Antoine Kalina, who wrote: 
"The Rromani language must be regarded as one, homogeneous and having the same rights as all others in the same family. It is the duty of science to know this language in the form of its own, to extract from all dialects the essentially Rromani common fund, to remove/clear from the pure metal the alloy that has accumulated there in the course of time and the combination of various circumstances. In order to achieve this goal, the best way would be to create a specific Rromani alphabet, based on a scientific basis and consistent with the sounds of the voice and its modifications in all shades. With the aid of this alphabet, the language would gain in lucidity; in addition, receiving a garment of its own, it would become more accessible to study, and free of all misunderstandings arising from its writing, currently based on those of the languages of the various countries and, as a result, so disparate and strange."

du pays: partout se manifeste le même esprit créateur,
imposant à tous les mêmes règles. A ce titre, la langue
tzigane doit être considérée comme une, homogène et
ayant les mêmes droits que toutes les autres de la même
famille. Il est du devoir de la science de connaître cette
langue dans la forme qui lui est propre, d'extraire de tous
les dialectes le fond commun essentiellement trigane, de
débarrasser le pur métal de tout l'alliage, qui s'y était
accumulé dans la suite des temps et par le concours de
diverses circonstances. - Pour atteindre ce but, le meilleur
moyen serait la création d'un alphabet propre à la langue
tzigane, reposant sur une base scientifique, conforme aux
sons de la voix et à ses modifications dans toutes leurs
nuances. Grâce à cet alphabet, la langue gagnerait en lu-
cidité; de plus, ayant reçu un vêtement qui lui fût propre,
elle deviendrait plus accessible à l'étude, et exempte des
malentendus qui naissent de son ortographe, aujourd'hui
basée sur celle des langues de divers pays, et, par con-
séquent, si disparate et si étrange.

Unfortunately, this wise and visionary proposal remained for a long time without echo.

\section{Ferenc Sztojka's dictionary}

It is however interesting to mention that in the same year, the Rromani violinist Ferencz Nagy-Idai Sztojka published his Hungarian-Rro- 
mani dictionary of thirteen thousand $(13,000)$ words, using Hungarian orthography, although he introduced the double $\mathrm{R}$ spelling in order to distinguish, for example, words like bar (fence) from barr (stone); or the word csórimosz (theft) from csórrimosz (poverty).

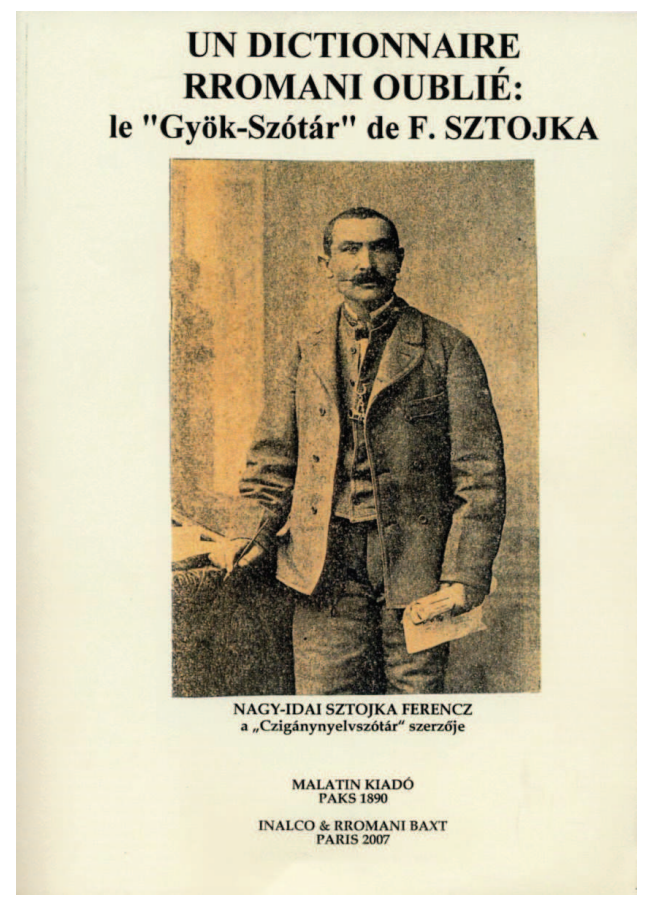

This Dictionary is of special significance because its author included at the end of the book 25 lyrical poems as to evidence that Rromani can be used for literary creation. This is, incidentally, the oldest literary corpus in the Rromani language.

\section{Soviet graphization (создание алфавита/письменности in Russian)}

When later Rromani literature developed in the USSR (1925-1938), the authors wrote in the local script, namely Russian Cyrillic, and using only the so-called Northern-Russian dialect of the Rromani - namely 
севернорусский диалекй иыйанскоїо языка, the one spoken in Moscow and therefore viewed as the "language of the capital city". As a result, this norm was rejected by all other groups of Rroms all over the Soviet Union. This attempt at promoting Rromani ended in 1938, when Stalin closed all institutions of nationalities lacking a concrete geographic district or area, due to a sudden back to basics ideas by Marx and Engels, who believed that maintaining cultural diversity is a trap set by the bourgeoisie to delay the victory of the Revolution.

Globally this first attempt of graphization for Rromani resulted in a failure due also to four more reasons:

a) a narrow dialectal basis was chosen as the paramount model;

b) every time a "word" (in fact rather a "notion") was missing, the Russian word was introduced without any concern for adaptation or understanding;

c) no one was concerned with any educational strategy toward Rroms in leading them to the universe of written language

d) The Rroms and the Rromani culture were despised as primitive, immoral, backward, unfitted for assimilation into the mainstream (which one?) way of life etc. - an assessment blatantly mirrored in schoolbooks and therefore unsuited to encourage literacy among Rroms.

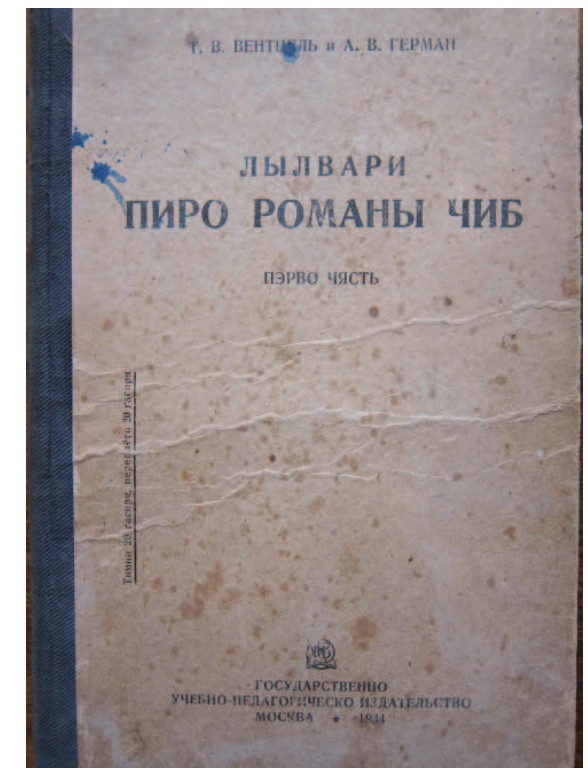

The first Soviet ABC-book in Rromani for adults 
Like the Russians before the war, in the 1970s the Hungarians released a collection of poetry in Rromani and Hungarian. Here the Rromani language is written according to Hungarian rules, just as Hungarians used to do with other minority languages in Hungary, for example, with Slovene, when printed Slovene devotional texts were written according to Hungarian spelling.

\section{First World Rromani Congress in London}

It was not until the first World Rromani Congress in London, in 1971, that concrete key rules for the standardization of the Rromani language were issued:

- It was recognized that the Romani language played an important rôle both as one of the distinctive features of the Romani people in each country in which they lived and as a link between different groups.

- The efforts of the English and Spanish Gypsies to restore their language to active use were approved.

- It was recognized that all spoken Romani dialects are of equal merit and that no one dialect is superior to any other dialect.

- Nevertheless there was a need for an international standardized dialect which could be used in periodicals and in congresses.

\section{The lila movement in southern Serbia}

Far from these theoretical, albeit very useful, Congressional hearings, there appeared among Rroms in southern Serbia and Macedonia a real passion for writing poetry in the Rromani mother tongue. Most of the authors just wrote a few songs with a typewriter and carbon paper: these young people used to read their (often naïve) verses during evenings of Cultural-Artistic Associations (K.U.D.) with their peers, and to exchange these texts in meetings from city to city (Niš, Leskovac, Priština, Kumanovo, Skopje, later Tetovo, Gostivar, Struga, Ohrid, Prilep, Titograd, etc.). It can be said that this was a kind of spontaneous, even somehow wild, poetic movement of young Rromani autodidacts - whereas in Belgrade a more elite type was in formation. 


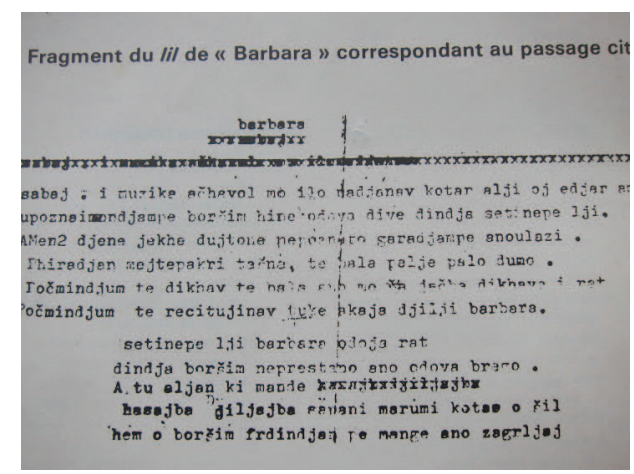

Fragment of the lil "Barbara" by Gafur Rašiti

In this context, the first difficulties related to the dialectal diversity of Rromani appeared. These were the years when there was no theoretical answer to the question of whether we are dealing with one or more Rromani language(s) and therefore these first attempts led to no concrete result.

\subsection{Ismet Jašarević's attempts}

A key step in resolving the issue of establishing a unified written Rromani language occurred, when in 1977-78. a young Rromani poet from Leskovac, Ismet Jašarević, strived to find a system of writing that could cover both endayolects in which he was creating: that of his mother (popularly called "gurbetsko" in Yugoslavia) and that of his father (popularly known as "arlijski"). Since we were already friends, he shared with me his concern and in conversation expressed his desire that poetry written in one dialect could be easily understandable for users of other Rromani endayolects. As he had noticed that speakers of both endayolects understand each other without much effort in oral communication, it was for him inconceivable that discrepancies could stop communication when put in written form, as if passing a text onto paper and into letters would create an invisible wall between these same speakers. 


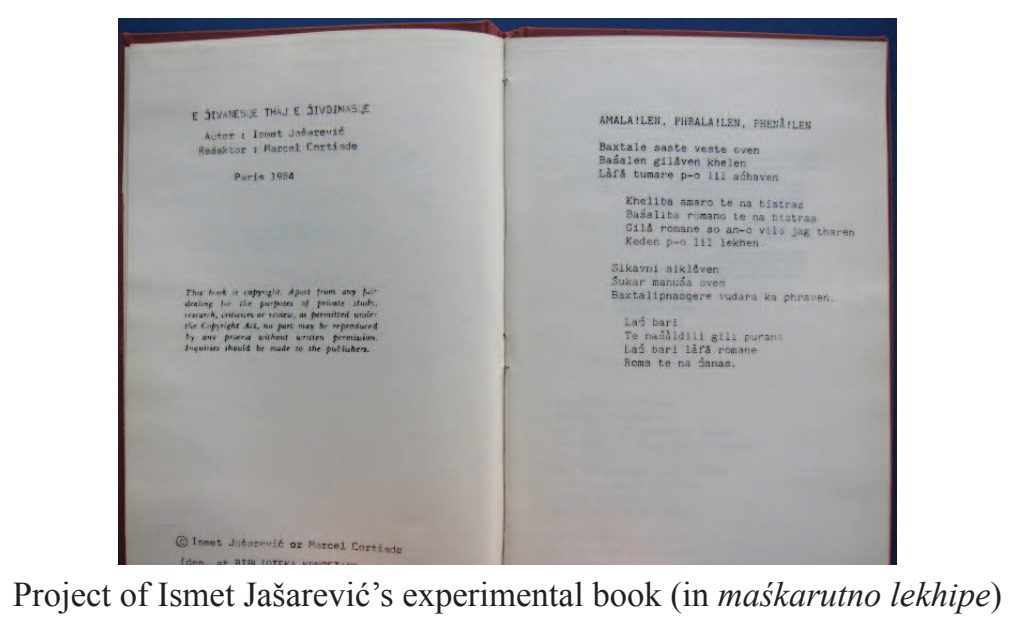

\section{Typology of dialectal differences}

At that point we started thinking about the systematization of the differences between endayolects. We carried out a dialectal survey in each of the dialectal varieties of southern Serbia, identifying them simply after their popular names. It should be underlined here that in former Yugoslavia every Rromani endayolect had a specific name, which is not the case elsewhere, for example in central or northern Europe. As an initial corpus, we took for the purpose of this enquiry Morris Swadesh's standard list and subsequently a series of 250 paradigmatic sentences encompassing not only Swadesh's vocabulary but also almost all phonetical, phonologic, morphological and to some extent syntactic, characteristic features of the various vernaculars. This led us to two conclusions:

A) All differences between various endayolects can be divided into consistent and non-consistent, which gave us the start of the typology of these differences, which we later presented at an international scientific conference in 1986 in Sarajevo. From this arose the idea that, for elements differing in a consistent way, one may use a common spelling, leaving to the speaker the freedom to read as he had learned to pronounce since early childhood. As a basis for writing, we began to propose taking the most archaic forms among two or more vernaculars. The reason is clear for ev- 
ery dialectologist: an archaic form can explain all derivatives, while it is much more difficult to explain the original form using a derivation forms: for example, we have introduced the written form of the word gili (song) to cover the following varieties of pronunciation: [gilji, ǵilji, Jilji, dzilji, giКi, gíi, JiКi, dziKi, gili, ǵili, Jili, dzili etc.] etc. On the other hand, in the case of non-consistent differences, writing was left literally as it actually sounds. For example there is no systematic interdialectal correspondence between the vowels [o] and [u] and we have both varieties zoralo and zuralo "strong", whereas in the word śov "six" we meet only [o]. Accordingly the possibility to use the spellings with $\mathbf{o}$ or $\mathbf{u}$ was left in the first case, depending on the actual pronunciation.

B) Another conclusion of this survey was to identify the various isoglosses which divide the Rromani language and to hierarchy them. We were able to establish this hierarchization, according to the typology of these differences and, among others, according to the probability of their occurrence in the languages of the world: some evolutions can occur in almost any language (based on articulary mechanism for example, or similar acoustic spectrum), while others are specific and therefore decisive for the classification of the dialects in the given language. An isogloss which emerged as a major beam of the whole dialectal structure of Rromani was the difference between vowel [o] versus [e] in the ending of the first-person singular past tense of verbs (phirdom with var. phirdǒm, phirdǔm, etc. versus phirdem "I walked, I went") and present tense of the copula (som with var. sinom, sinǔm, hinum etc. versus sem "I am.").

Contrasting with languages of historically sedentary peoples, Rromani isoglosses are not all geographical and it is amazing to see some works in Rromani dialectology treat all of them on a foot of equality. Actually, the oldest isoglosses are widespread all over Europe (and overseas) and the o/e isogloss belongs to them, creating both the O- and E-super-dialect, to be found in almost all European countries (the o/e isogloss is part of a bundle of some 12 isoglosses - all dating back before the first expansion of the Rroms in Europe). Another isogloss to be found almost everywhere is the Mutation of two of the Palato-Alveolar Affricates (M2PAA) 
(evolution of [th] into [6], concomitant with the evolution of [ds] into [z]). Later on, after the first general settling of the Rroms, some other isoglosses appeared locally and they are indeed related to the geographical distribution of sedentary Rroms, for example the ending in medio-passive of the type kalilo, kalili versus kalilăs "it went black", the secondary infinitive etc. In addition, there are some very local isoglosses, of weak significance for wide dialectology, as for example apakăl "to believe" versus common Rromani pakăl in south-western Bulgaria or the local imperfect of the copula avlòsa, avlìsa versus sèsa, sine etc.

The XIX century migrations have substantially complicated the dialectal map of Europe, as well as the most recent migrations. However, it is possible to conceive the whole system, provided the hierarchy of isoglosses in terms of specificity, chronology and extension is respected.

We conducted also further analysis of the collected corpus, then not only in the south of former Yugoslavia, but extending the circle of analyzed Rromani dialects first to Poland, the Soviet Union and Italy and later on to other countries. We gathered also the lexemes of different texts ranging from artistic creation of renowned Rromani writers to ethnotexts and field-work surveys - always in the perspective of the typology of dialect differences.

\subsection{Dialectometry}

The above mentioned research provided us with a more accurate picture of the structure of relations between Rromani varieties. However, the basic question remained: one or several Rromani language(s)? In search of an answer, we resorted to the dialectometrical method and attempted to measure mathematically the "distance" between varieties, taken two by two. This approach revealed that the rate of commonality $\mathrm{T}$ of the dialects fluctuates between $88 \%$ and $95 \%$ when calculated on the basis of the pronunciation of Swadesh's word list (since Jacqueline Manessy-Guitton, $81 \%$ is usually taken as a border rate between language-to-language [T $>81 \%$ ] and dialect-to-dialect $[\mathrm{T}<81 \%$ ] relations; to make these values

more conspicuous, the T of French-Italian commonalities is 39\%). Out of this rate of commonality, one may calculate a dialectometrical distance $\mathrm{d}$, 
thanks to a series of coefficients calculated in such a way that a distance $d$ greater than one between vernaculars indicates that their represent separate languages, while in the case of dialects of the same language, the distance $\mathrm{d}$ is less than one. The result of the analysis evidenced that all reviewed Rromani endayolects belong to a unique and the same language, as the greatest distance was 0.7 unit, namely between a Sinto dialect from northern Italy and Kelderaś from Moscow. These results were published in 1982 years in Poland, and two years later in the USA.
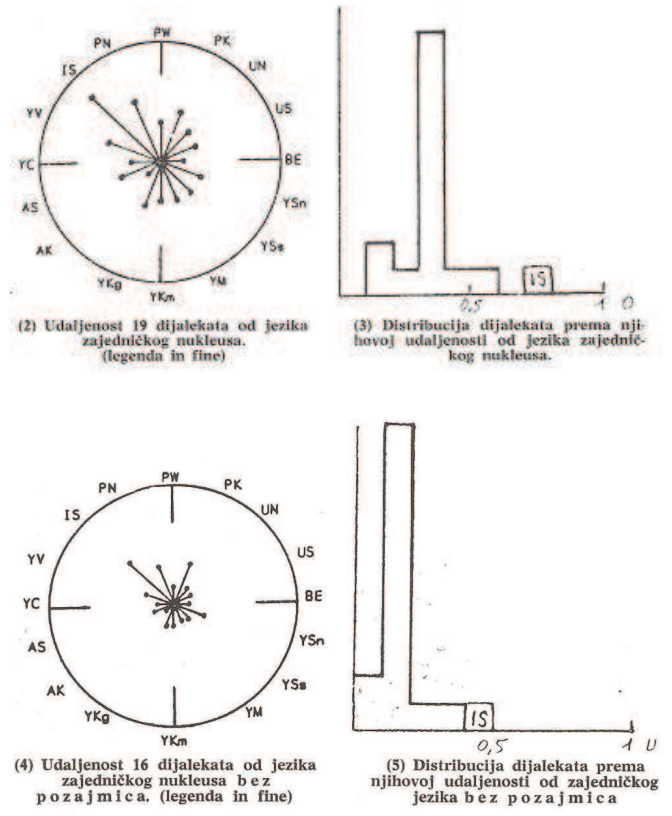

\subsection{Expansion of the project}

We worked further on the material of Ismet Jašarević's poems but we also included those of the late Dževat Gaši, Disoran Zekiri, Isljam Rašiti and many others, including even elite songs by the already worldwide famous Rajko Djuric. We published experimental brochures with suggested common rules of writing, while extending the circle of participants in this common aspiration. In fruitful discussions participated especially Rajko Đurić from Belgrade, but also Šaip Jusuf, from Skopje, co-author of the 
first grammar of Rromani written in Rromani language (drawn up actually after prof. Krume Kepeski's grammar). In the meantime, we had the pleasure to welcome to our circle various individuals, non linguists, but with a good media practice of languages, as well as many Rromani students, who were sharing with us the same goal: Orhan Galjuš, Ljumnia Osmani, Ganimeta Ramadani, Ruždija and Izeta Sejdović, Gordana Sejdić, Kujtim Paćaku, Dragan Saljković, Šaban Iljaz etc. There has been a big step forward when we realized that the backbone of the Rromani phonological system relies on the opposition between yotized and non-yotized vowels, more or less as in old Slavonic language.

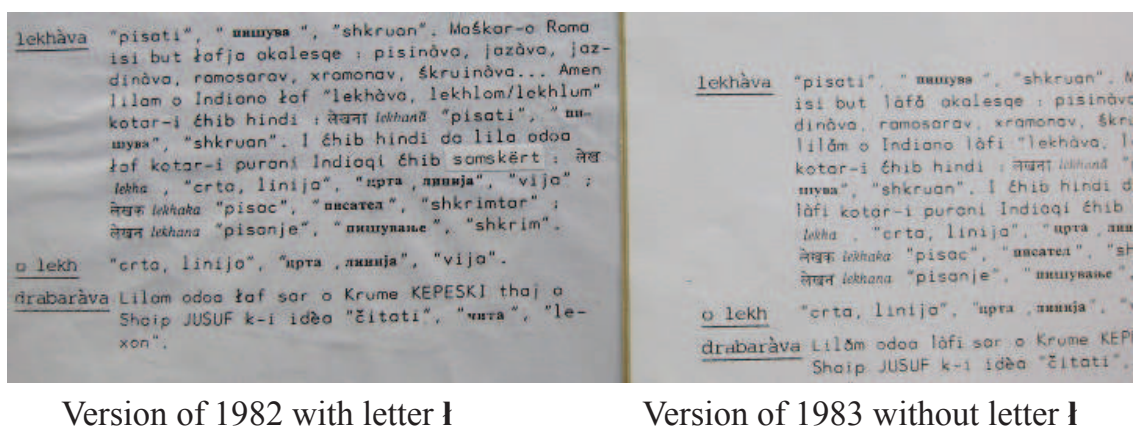

Until 1983, we were still accepting a phonological opposition between two lateral consonants, which were written 1 (for $[K]$ ) and $\nmid$ (for [1]), while in 1984 we understood that this opposition (difference, contrast) was operating much wider than with lateral liquids : it is in fact a phenomenon of yotization, linked not to the preceding consonant, but to the following vowel, and we used the inflex accent above the given vowel: ă ó ǔ etc. to denote it.

\section{Echoes and similar approaches abroad}

This progress was welcomed by researchers in linguistics from Poland, England, France and the USA. In the same year we printed the world's first anthology of Rromani poetry, which appeared in the Occitan language, as an illustration of the birth of a new poetic voice in former Yugoslavia, a "true spiritual paradise for the development of the cultures of the various peoples and nationalities" (quoted from the foreword) and it 
is true that Rromani creativity really achieved then a unique blossoming in Yugoslavia - with no counterparts in other countries.

We thought we were alone at work in the field of promoting written Rromani in an interdialectal perspective. However, when the French journal "Etudes tsiganes" released the first part of our article "Young Rromani poets from Kosovo" in 1982, we discovered with great surprise an article by a Latvian Rrom from Moscow, Leksa Manuś: in his article he was publishing and commenting on his verses, written in fact in such a way as to enable every Rrom in the USSR to read them according to his/her own pronunciation and understand them on principles similar to those in use in the former Yugoslavia. The main problems faced by Rroms in the USSR were linked to the diverging pronunciations of certain vowels: e.g. some Rromani groups utter words like śukar, maśkar as шукыр, машкыр or шукир, машкир. Leksa Manuś always wrote śukar, maśkar but used to add two dots for Rroms who pronounced the end as [ir] or [ir]: śukär, maśkär, rather than simply writing śukyr, maśkyr or śukir, maśkir. Another problem was related with the mutation of the 2 palato-alveolar affricates [ $\mathrm{th}]$ and [ds] and his solution was to write the Cyrillic letters $\mathbf{4} \times$ and $\dddot{\varkappa}$, with the rule that everyone reads as $\mathrm{s} /$ he has learned in his/her childhood, after his/her dialectal pronunciation, namely [th] i [ds] in vernaculars without these mutations and respectively [6] and [z] in those with the given mutation

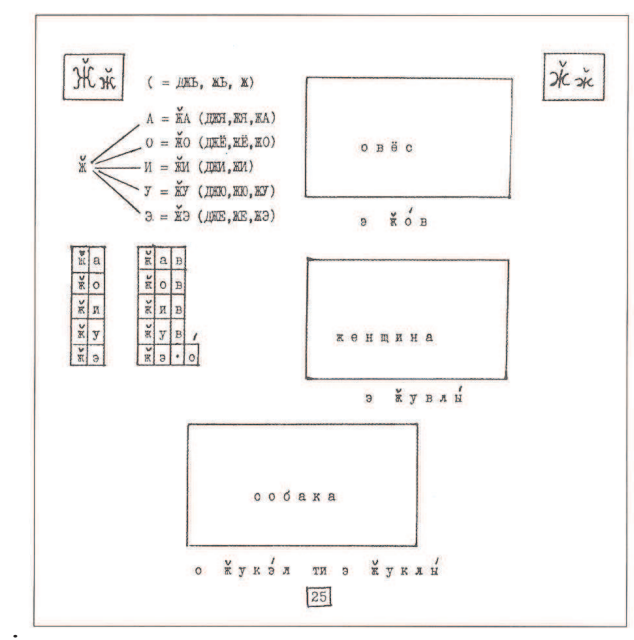


The parallelism of our undertakings meant that time was already ripe for the idea of a polylectal alphabet for the Rromani language. We presented all these achievements at the international scientific conference "Rromani Language and Culture" in Sarajevo (June 1986). We introduced primarily a comparatively detailed typology of interdialectal differences but we also presented the results of the lexicon-statistical and dialectometric researches on the distances between Rromani endayolects, then not only as two-by-two intervernacular distances, but as distances calculated in respect to a few typical endayolects, disregarding recent superficial changes such as trivial palatalization ( $\mathrm{ki}>$ ći), the closure of some vowels and so on. While measuring these distances, we conducted in parallel calculations on the one hand between vernaculars in their factual condition, namely including recent loanwords, and on the other hand without these loans. Then we noticed that the distribution of distances presents a rupture (see diagram), which expresses a gap amidst the distances between vernaculars that have the vowel [o] at the end of the first-person singular present tense copula (and past tense of verbs) and those with [e] in this position. This was the visible rendering of the separation between $\mathrm{O}$ - and E-superdialects. The second group is divided in turn into two subgroups: without mutation and with mutation, because we thought then that there are three layers of Rromani dialects, due to the fact that we have not yet come across endayolects of the O-type with mutation. Nevertheless, we left open the possibility that, one day we could find such a dialect. This was confirmed 10 years later, when we found in Hungary a subgroup of type [o] with the mutation (the Cerhàri), and by then it became clear that there are two super-dialects in the Rromani language: one of [o] type, where the overwhelming majority of endayolects have not undergone mutation, and the other one, of [e] type, where almost half of the endayolects went through mutation. But all this happened later. Let us return to the conference in Sarajevo. By way of conclusion, we set forth the joint proposal for the Rromani alphabet, which was derived from the work of our team, and the editors of the conference proceedings gave us the opportunity to test this alphabet: they ordered after each presentation in the book (there were over 50) a summary in the Rromani language (then called "central Rromani language") in the proposed alphabet. A Rromani-Serbian-English Lexicon of neologisms, internationalisms and rare words used in Rromani summaries was inserted at the end of the book. 


\subsection{The Titograd Phonetics}

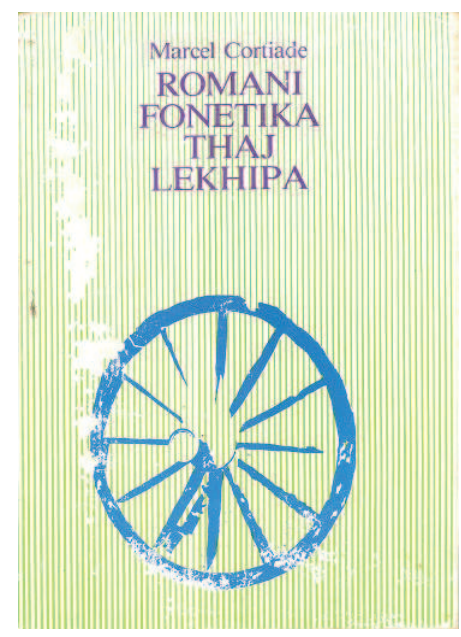

That same year, the Montenegrin publishing house "Pobjeda" issued the final version of Romani fonetìa thaj lekhipa (Rromani phonetics and writing), which had already been circulating in public among Rroms in an experimental form only in Rromani. In the "Pobjeda" publication the whole text was printed bilingually (on the left side in Rromani, on the right side in Serbo-Croatian). The preface of the book, written by Šaip Jusuf from Skopje substantiated his personal support. The book was completed with a selection of poetry by Rromani authors from different countries so as to illustrate the possibility of using one single alphabet everywhere in Europe. All this achieved merely one step towards standardization of the Rromani written language. Conditions were already ripe for an attempt to print the first primer of Rromani language - which was prepared on order of the publishing house "Svijetlost" from Sarajevo. 

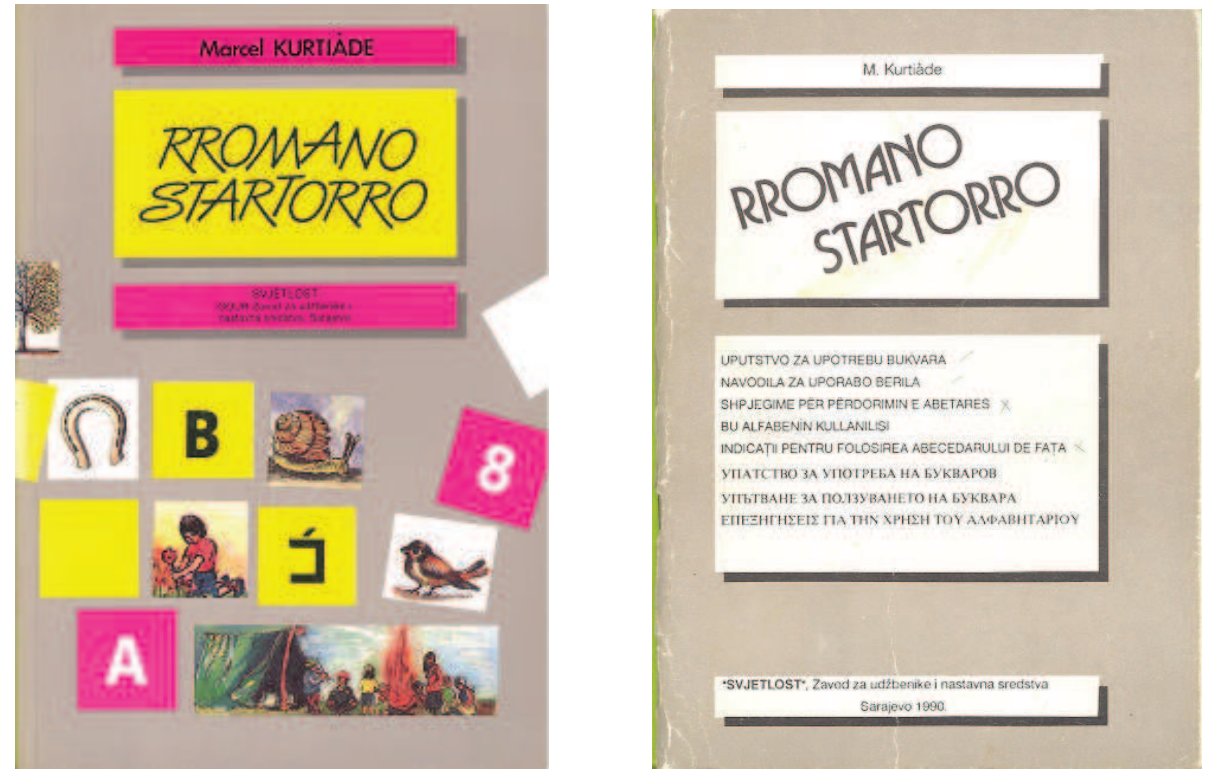

The first (out the Ussr) Rromani language primer. Booklet of instructions in the languages of the SFRY

\section{The IV-th Rromani World Congress in Warsaw in 1990}

The next step took place in spring 1990 in Warsaw on the eve of the IV-th Rromani World Congress. In the preceding days, a three-day linguistic consultation was organized, in which 18 experts, mostly Rroms with Rromani as their mother tongue, participated and discussed the final details of the newly established form of Rromani writing, after a long mutual correspondence in previous years.

A crucial role was played by Dr Rajko Đurić, who for example rejected the seven-vowel system for the Rromani common vocalism, as presented by Marcel Courthiade ( $\mathbf{a}$ e ë i ï $\mathbf{0}$ u), and introduced a system of only five vowels (namely a e i o u - thus without ë and ï). Further investigation revealed that his intuition was quite appropriate and that the vowels $\ddot{\mathbf{e}}$ and ï are only local varieties of cardinal vowels. 


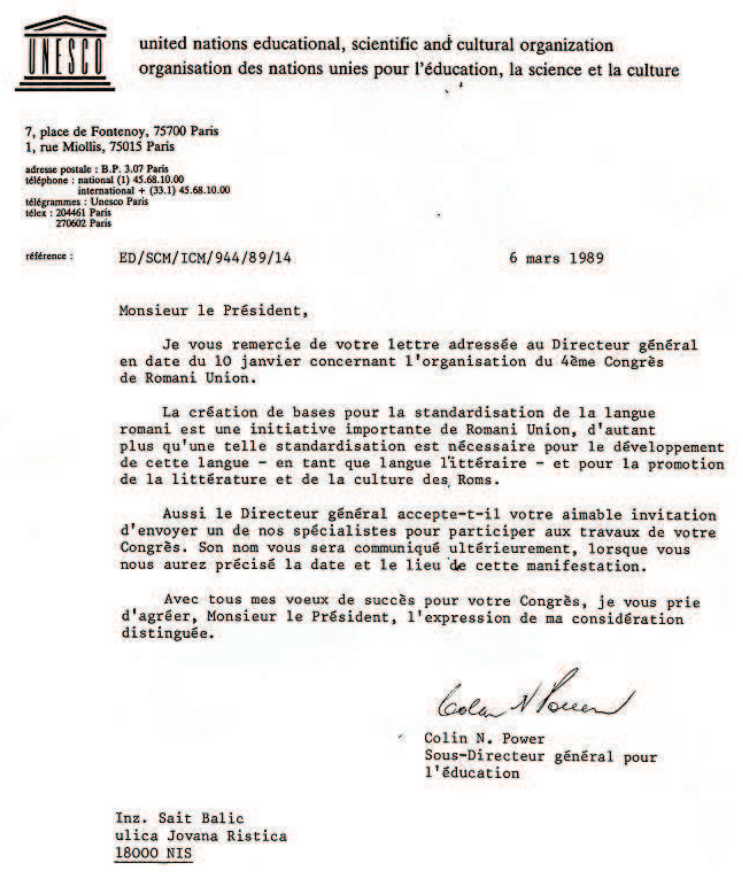

Letter of support on behalf of the UNESCO to the Warsaw Congress

The experts opted for the system of five vowels. Another contribution by dr Rajko Đurić was also significant, because he rejected the sound [c] (as in dialectal Rromani rrëndza "tripe", palëndza "scale (to measure weight)"), as an integral part of the Rromani system of palatal affricates. In fact, Marcel Courthiade's system of eight palatal affricate consonants (namely including [dz]) was inspired primarily by Macedonian phonemics.

The elimination of the sound [cz] as a separate phoneme made unnecessary the creation of a specific letter to render it in script, and there were no more need of logical graphic coherence with the letter rendering the sound [dz] (since they would have to be connected). Under such circumstances, dr Rajko Đurić suggested to render [ds (and incidentally z)] by means of the old-Italian letter 3 and all the participants agreed. Discussion focused further about how to write the specific Rromani /r/, the one in contrast with [r] and some Rroms, who do not have such a special sound in their own vernacular, did not realize the importance of introducing a 
specific letter. Participants took then two positions: either to introduce the regular letter R with diacritic signs (e.g. R, $\mathbf{R}, \check{\mathbf{R}}$ etc.) or the digraph $-\mathbf{R r}$.

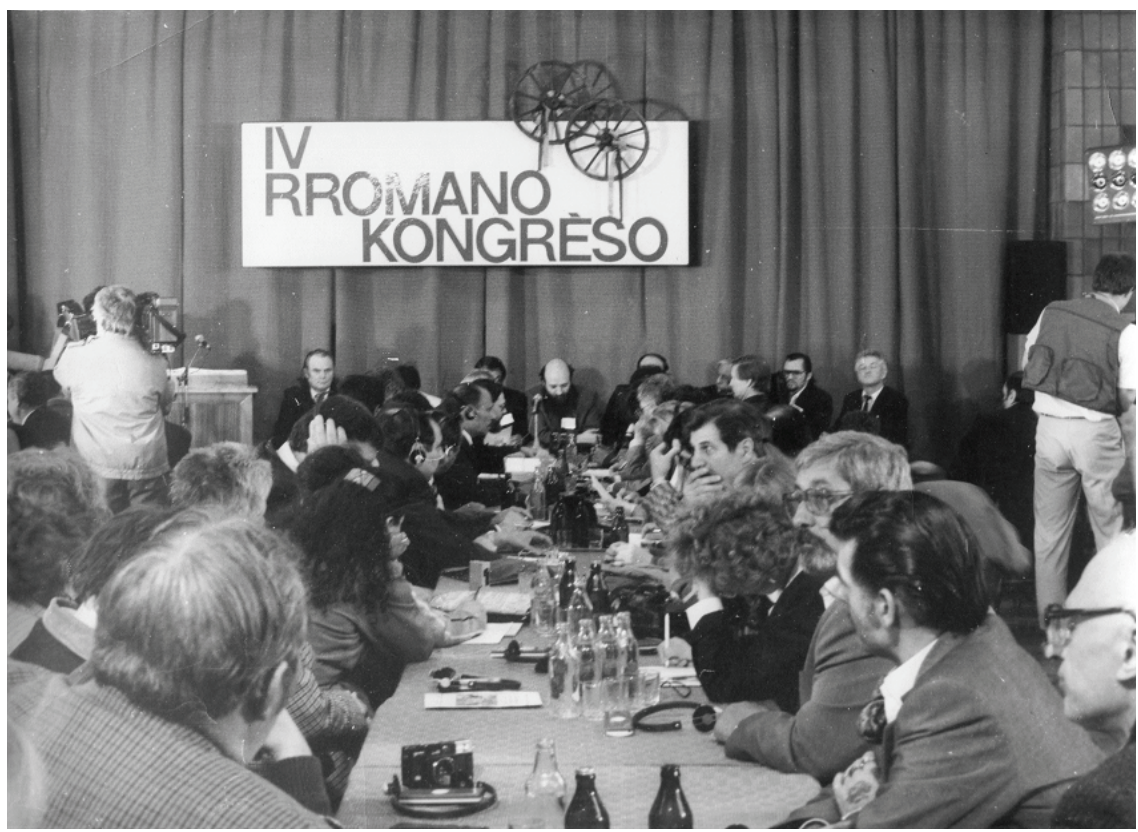

At the end, the experts voted to use double $\mathbf{R}(\mathbf{R r})$, because it has an already long tradition, starting from the first dictionary ever written by a Rrom-lexicographer (vid. supra). Another argument for the double $\mathbf{R}(\mathbf{R r})$ was simply that the sound can be heard at the beginning of our ethnicon - Rrom. Should journalists and scientists, members of the majority nation, want to write it correctly in mainstream publications, it will be much easier to use double Rr, than for example Rom or Řom with accented R. At the issue of the consultation, 17 participants (out of 18) signed the "Declaration on a joint Rromani alphabet and its polylectal use". The declaration was also signed by Professor Viktor Koptiłov, from Ukraine, head of the UNESCO delegation to the World Rromani Congress and director of the UNESCO program Linguapax. One should also mention that $\mathrm{Mr}$ Colin Powell himself, in quality of vice-secretary-general of UNESCO, welcomed the initiative of the Congress and the standardization of the Rromani language at the global level, in two very cordial letters. 


\section{The implementation of the common Rromani alphabet in school - especially in Romania}

Shortly after the Warsaw Congress and its Declaration on the polylectal alphabet, the Romanian Ministry of Education and Technology, introduced teaching of Rromani language and culture into the state school system, with Rromani written according to the rules of the Warsaw Declaration. This Decree still applies to date and we can point out that for the past 25 years of its existence, nearly half a million of young Romanian Rroms went through the process of learning their mother tongue and culture (with currently an average of 30,000 to 35,000 per year).

In 1992 the EU Commission decided to print the first Rromani ABCbook according to the Warsaw rules, while the Council of Europe took over the task of distributing it in different European countries, together with a booklet of instructions for its use, issued in the following languages: English, French, Spanish, Slovak, Hungarian, Romanian, Serbian and Albanian. The common Rromani writing and reading were also introduced to Italy, France, Spain and Macedonia. In Macedonia, Lâtif Demir printed several books and magazines, using the already established international rules.

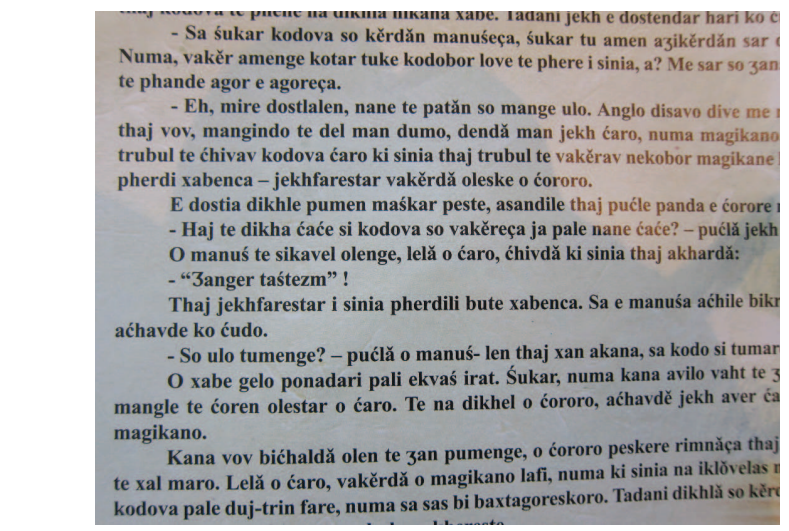

Example of book by Lâtif Demir, printed in common spelling

We may present the stages of diffusion of the Warsaw standard as below: 


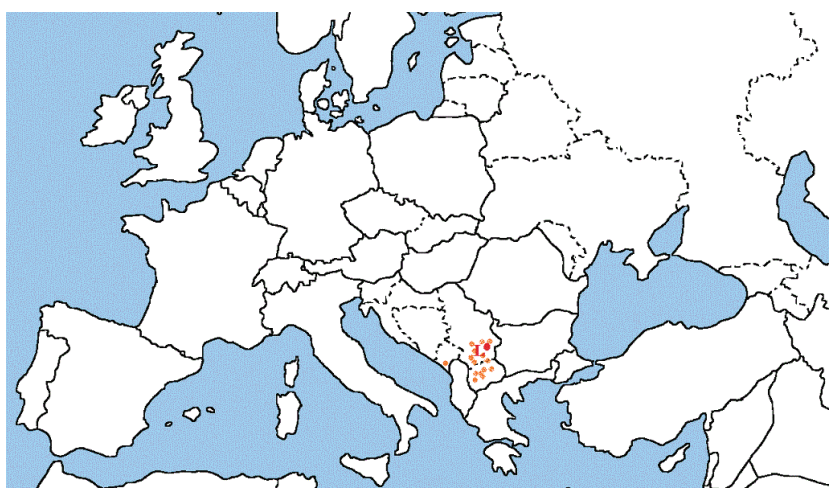

Beginnings of standardization i SFRY (1980)

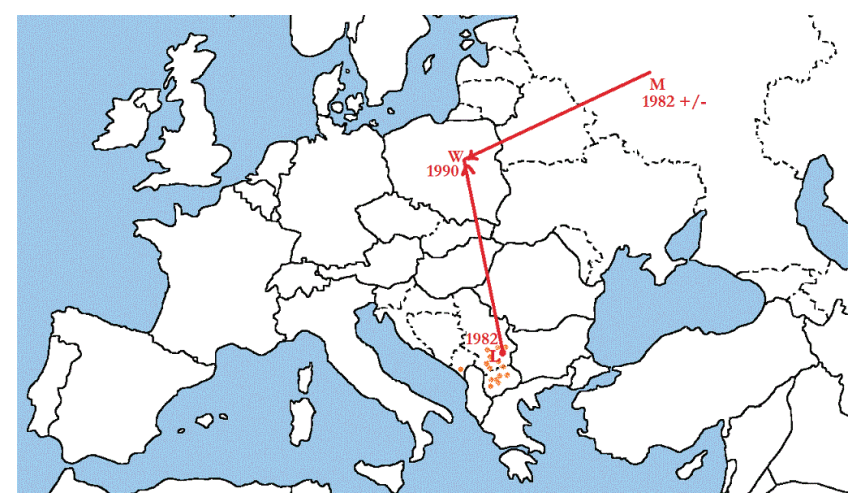

Meeting of the Yugoslav project with the Russian proposal from Moscow (1990)

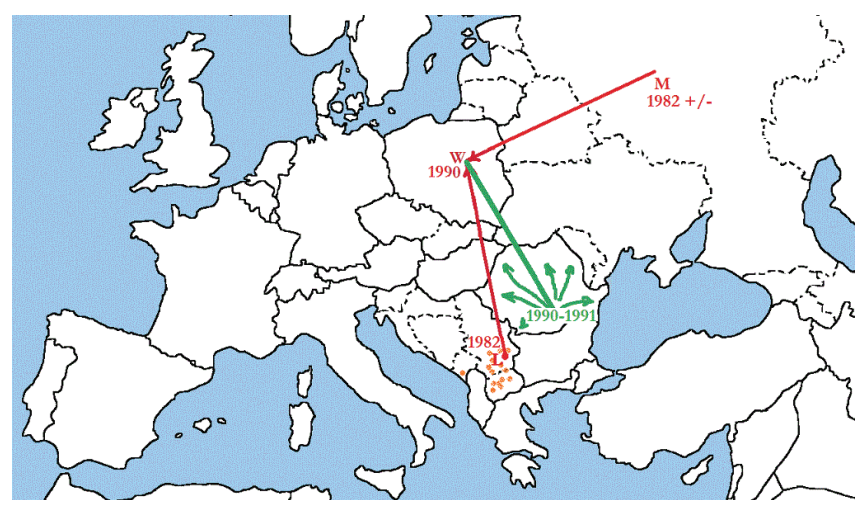

Expansion of the common alphabet in Romania (1990-91) 


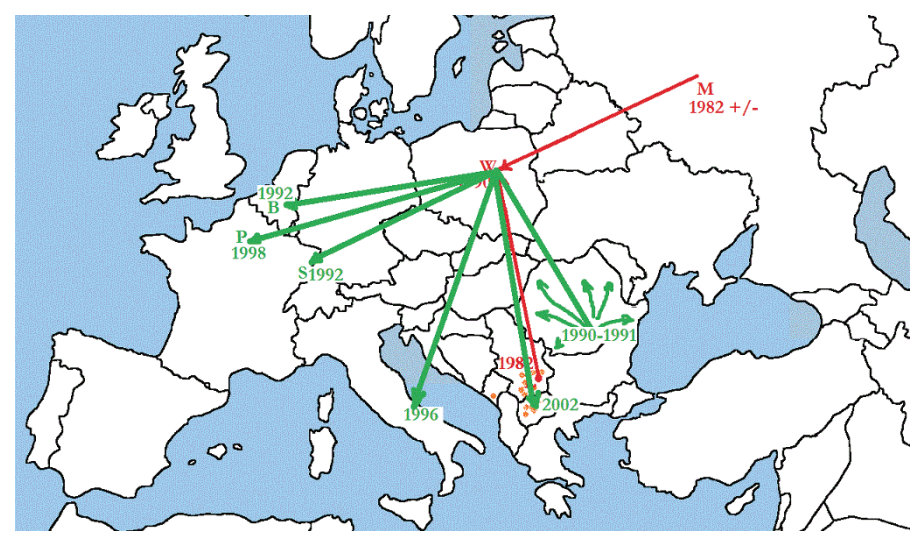

Further expansion in Europe (1992 to date)

\subsection{Croatian-Bosnian resistance in favor of the Czech-Croatian Latin script}

In 2008, an unexpected move took place in Croatia, where the president of the Association "Kali Sara", Veljko Kajtazi, asked the IRU Commission to proofread and correct his Croatian-Rromani and RromaniCroatian dictionary, which was done for free. Unfortunately, according to Kajtazi's testimony, a group of Croatian nationalists exerted pressure and personal threats upon the person of Kajtazi's printer and publisher not to allow the printing of the "Gypsy language" of Croatia in a different alphabet than Croatian Latin script. I do not deny that Croatian Latin script is appropriate for the spelling of the Croatian language, but it is doubtless inappropriate for any other language, such as Hungarian, in English or French, and of course also for Rromani. They probably acted like this in order to set up barriers between the Rroms of Croatia and those in other countries, the more so because the Rromani issue was the subject of manipulations on the eve of the country's accession to the European Union.

Unfortunately, Croatian separatism also infected Bosnia and Herzegovina, where some Rromani activists developed some scientific ambitions to teach Rromani at a high level, although they did not have any qualifications or competence in the knowledge of either the language or linguistics. 


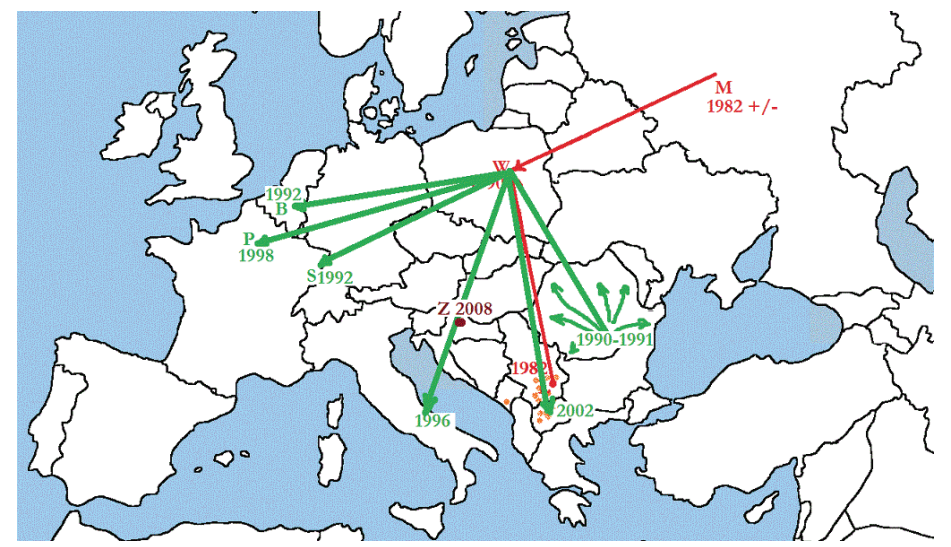

Emergence of the Croatian-Bosnian opposition (2008)

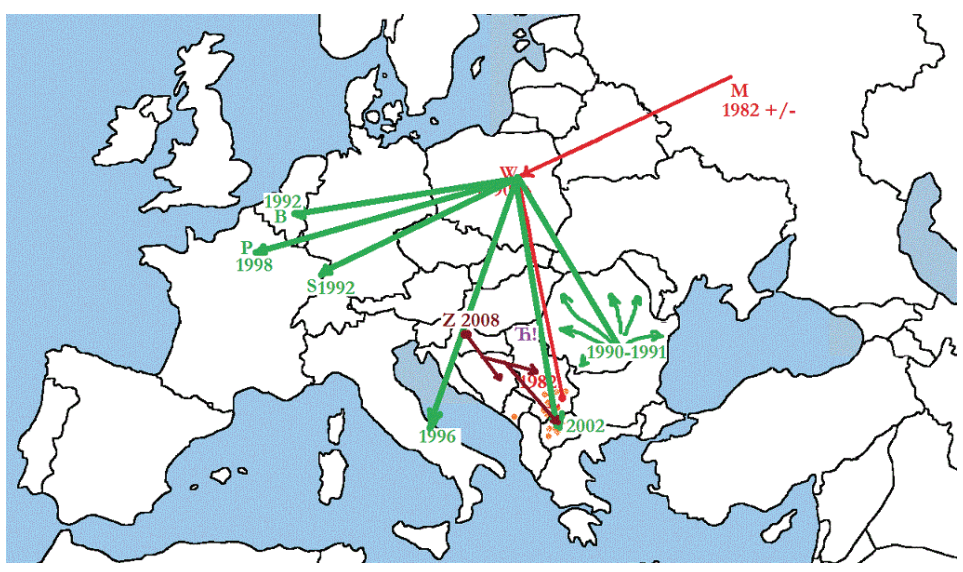

Diffusion of the separatistic alphabet

The following incident was caused by their close friend and collaborator (Lâtif Demir) who gave up the international standard, although he had personally introduced it earlier to Macedonia and began to propagate the Croatian cacography to enable his close friends and collaborators to easily understand written Rromani and also to satisfy Croatian nationalists. He organized an allegedly specific standardization conference of Rromani, addressing only the countries of ex-Yugoslavia. His aim was to promote a "new" Rromani version of the Croatian writing system, regardless of the fact that this writing did not differ from the one used in the first Rromani spontaneously written and printed texts, immediately after World 
War II in Croatian script, such as for example by Rade Uhlik. These do not differ from today's Croatian writing, except maybe the project of using the group ya instead of ija (Marya instead of Marija - writing $y$ [or $\ddot{y}$ ] for $i j$ is in fact quite frequent in Dutch). The system has contaminated as well several Rroms from Serbia, who do not know the history and triggers of this specific separatism. Basically, the level of discussion of this supposedly "new" standardization is indeed extremely low, as one may conclude from one participant's complaint: "what kind of a doctor in linguistic are you, if you do not know that a letter and a phoneme are the same thing?" Another claimed that the letters $\mathbf{q}$ i ç are to be found exclusively in the Albanian alphabet etc. They succeeded thanks to subsidies of different origin to print several brochures and declarations, some of which signed by dr Rajko Đurić, albeit a former active participant in the international consultation for the standardization of the Rromani language and twice a signatory of the Warsaw Declaration (the first time in his quality of expert involved in the Warsaw consultation and the second time, in another separate document officializing the Declaration, as the President of the International Rromani Union). Something in all this remains yet unclear: during that period dr Rajko Đurić was seriously ill and immobile, while later, when he recovered, he supported in writing the Warsaw system. Be it as it may, all this shows the total ordeal through which this language, the unified homeland of the Rromani people must go through, due to so many low and selfish interests.

\subsection{The Kosovar resistance in favor of an "adapted" Albanian-based alphabet}

Of course, one can not overlook the fact that Serbia has long been isolated from the world due to the blockade, and the international sanctions then imposed - precisely in the most important years in the European affirmation of the Rromani language. In this atmosphere then appeared in the country inner conflicts around Rromani writing, because some non-Rromani individuals and groups in Novi Sad pushed Cyrillic for religious-nationalistic purposes. At the same time, the intrigues of several Kosovars began to influence Serbia, primarily Ibrahim Elshani (known in 
his community as a "gynecological-obstetric case", because he was born as a Rrom only at the age of 60 years) and Selahedin Krijeziju (both from Prizren). These properly called dilettantes tried to impose upon Rromani a simplified form of the Albanian alphabet, convinced that a language has to be reduced to its most rudimentary and simplest expression in order to blossom (mininmal alphabet, simplified morphology and vocabulary etc.). A third person, equally from Prizren, Ljuan Koka, decided with no clear reason that Serbian Rroms should use a different Latin alphabet than other Rroms in Europe, maybe to prevent international written communication, and perhaps in order to obstruct the affirmation of a common Rromani language. Such a language, in the opinion of xenophobic politicians, could allegedly lead to the recognition of a Rromani nation and consequently to the appearance of Rromani political forces on the European political scene, camarillas of "wild Gypsy indignitaries" - following their already deeply rooted phobia. This fear of a modern Rromani language, with a common alphabet, is not limited to the former Yugoslavia; it is common to all European countries and was expressed recently in a book by the Italian anthropologist (and reportedly also a police informer among Rroms) Leonardo Piasere, who wrote: "The Gypsies already had a flag and an anthem, now with the alphabet, they have at their disposal the perfect nationalist triangle". Beside these persons, reluctant to accept any Rromani affirmation, other loud polemicists came out and, as for example in Preševo, also without the slightest scientific argument, began to promote the Croatian Latin alphabet. All these pseudolinguists from southern Serbia keep usurping a large space on the Internet with empty polemics (they have time for they are not involved in research or creation, just in controversy for selfpromotion), but none of them has even written a single serious essay, study or expert analysis on the subject of Rromani language and Rromani spelling. Through these subversive interferences they only favor all those who prefer to see Rromani as a language, and consequently Rroms themselves, remain on the edge of society, abandoned to the flows of history to disappear. Because of these unfavorable conditions, progress has emerged very slowly, through obstacles and difficulties, and we may observe until now many traces of these conflicts, caused by the ignorance and selfishness of people involved in discussions and decisions, but who are actually marked 
by a tragic lack of profesionnalism and a total absence of natural ethics or national devotion within the members of the Rromani people.

\section{Technical advances in favor of a common Rromani alphabet}

While amateurs were fighting in Serbia (for the non-Rroms' greatest fun), the famous company Microsoft, on the other side of the world, introduced into computer systems the entire Rromani alphabet, including yotized vowels ă ì ǐ ǒ ǔ, the letter 3 etc... Another company, Glossoconsulting, produced the EuroUniv executive driver (or patch), enabling any user to write very easily in Rromani (as well as in 50 other European languages) on any computer, without shifting the linguistic option and the keyboard. Most European Rroms use this patch, but the information about it has not yet reached Serbian Rroms. The Japanese researcher Watabe Masako has independently elaborated a NooJ-module for Rromani, thanks to which electronic grammars and dictionaries may be created, substantial corpus may be treated, spelling may be checked etc. This NooJ-module is also a significant step toward Rromani to English and English to Rromani machine translation.

\section{Current situation in Serbia}

Today in Serbia, the situation still looks pretty sad: groups keep fighting, each of them pushing its own variant of written Rromani, be it the Cyrillic alphabet or the Croatian Latin alphabet, sometimes with the letter $\mathbf{y}$ instead of $\mathbf{i j}$ in Vojvodina, or even more local varieties as in the south of Serbia, and of course above all the Warsaw alphabet, promoted by the "Belgrade circle" - which has recently released several titles: three dictionaries by Bajram Haliti, a few devotional (orthodox) texts, then some editions of reading pieces, textbooks, a history of the Samudaripen (nazi genocide of the Rroms), a collection of poems devoted to this tragedy, a gorgeous tale in verses ridiculing racial prejudices (e Snićilă), Esop's tales, the moral Indian tale E sapenqi loś (extract from a play by Harșa), a new primer of Rromani etc. 
However, rumors are still circulating in Serbia (and wider in the former Yugoslavia, especially in Croatia) that "Rromani is (allegedly) not standardized". Beyond the refusal of some negationists to acknowledge the reality, there is a background of misunderstanding: many people do not realize the real meaning of the word standardization (as they don't understand what language, dialect, grammar actually mean in scientific terms) and do not know that one has to distinguish between primary standardization and secondary standardization. Primary standardization covers codification (or graphization, the elaboration of a written code with a set of writing and reading rules), punctuation and basic normalization (the main guidelines and principles of grammar and lexicology: the vocabulary itself abut also the treatment of archaisms, dialectalisms, neology etc.). Rromani primary standardization was achieved around 1990 - just as Serbian primary standardization was achieved by Vuk Stefanović Karadžić (1787-1864).

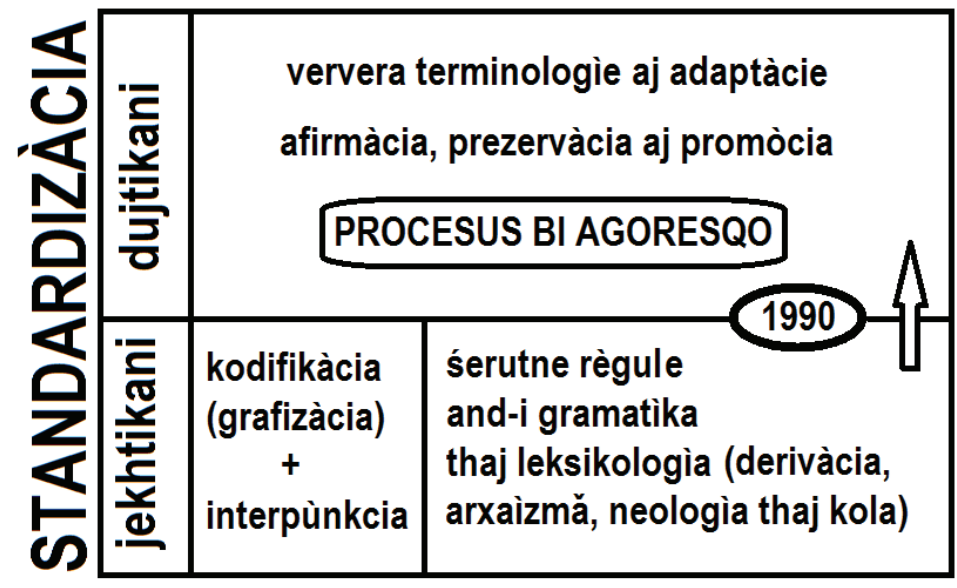

In addition, every language needs a "lifelong, endless" secondary standardization which deals mainly with new terminologies, adaptation of foreign words, development of IT in the given language etc. while working for its socio-political and cultural affirmation, its preservation (meaning coherent development in such a way that it remains widely understandable by native speakers and foreigner who have learnt it) and its promotion in as many spheres of human activity as logically requested. Over 120 languages of the world have a special committee, be it state-owned, associa- 
tive or private, in charge of secondary standardization. In 1997, one century and a half after Vuk S. Karadžić's "victory" in 1847, a specific Board for Standardization of the Serbian Language (Ogбор за сйанgарgизаиију срйскоі језика) was created in Belgrade; this doesn't mean that Vuk S. Karadžić's standardization is disregarded, but only that his standardization was the primary one and the newly established Board will carry out, probably during decades or centuries, the task of secondary standardization. This is the same with Rromani and the Board devoted to its secondary standardization is the Commission for language and linguistic rights of the International Rromani Union.

Another misunderstanding is related to the contradiction between the respect of the various vernacular forms of Rromani and the European tradition of a unique standard. Although this tradition is not fashionable anymore, in principle, it has spread very deeply in the mentalities of adults. However, children understand this natural situation much better. The coins of one Euro give a good representation of unity through plurality:

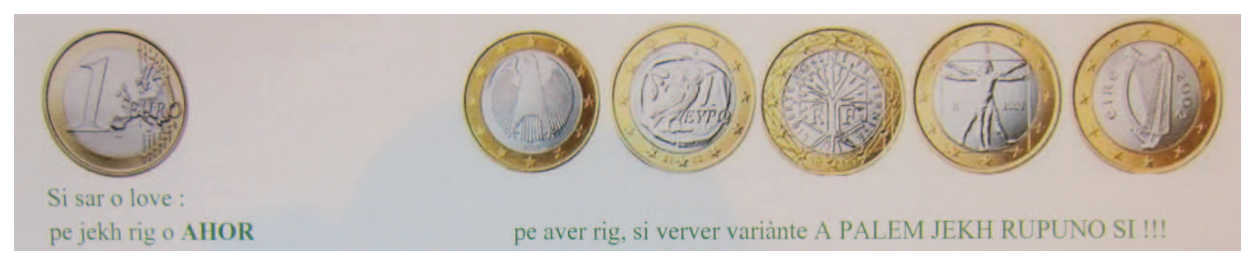

On the left side, the reverse shows the unique value of $1 €$ for all national coins: this is equivalent to the value of a given letter, and on the right side the various national obverses display various symbols (here German, Greek, French, Italian and Irish obverses): this is the equivalent of the various local pronunciations.

\section{Conclusion (of a kind )}

Blatantly, the solution is no longer in the hands of experts, scientists, linguists and standardologists, but in those of politicians with not even a minimal knowledge in the given scientific field of linguistics. At the same time the solution is no longer sought in rational, scientifically based decisions but in their impulsive and transient desires, often under pressure 
from non-Rroms, who have no connection at all with the stakes. It is by no means pleasant to observe that the fate of a language spoken by half a million Rroms in Serbia, and a heritage of 15 million Rroms all over the world, is treated in such a frivolous way, but in fact we are facing a wider socio-political, if not philosophical, problem: just observe how humans treat frivolously the environment and planet Earth, playing down issues of the utmost importance not only for one group of people, but for the whole of humanity... A solution to the fundamental and vital questions of a people, such as the fate of its tongue, is under the greatest threats, when the decisions are put into the hands of allegedly "democratically" elected (in fact arbitrarily named), ignorant and unconcerned so called "Representatives". Maybe any confidence in the flourishing future of Rromani and of a modern culture for Rroms in Serbia is lost, but at least we know clearly the causes.

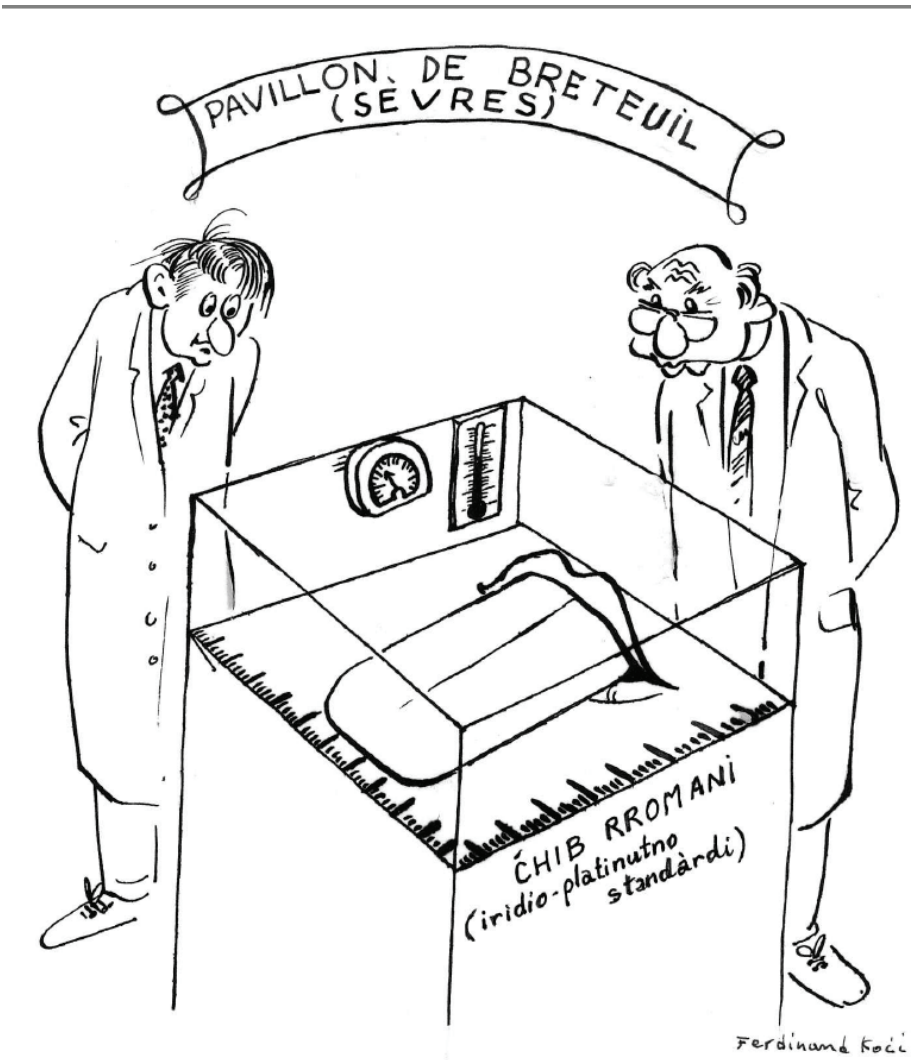


« Sar khetano standàrdi, amen na kamas jekh ćhib bi variacienqo ta unifòrmo, phandini anda jekh jekhutno modèlo ta stop. Pe aver rig, na kamas ni jekh vitrìna bute ulavde ćhiběnqiri, save peren and-i izolàcia thaj kotar-i izolàcia and-o meripe... » (... As a common standard, we do not want a language without variations and uniform, withdrawn in a single model and full stop. We do not want either a showcase of many separate languages that fall into isolation and from isolation into death. ")

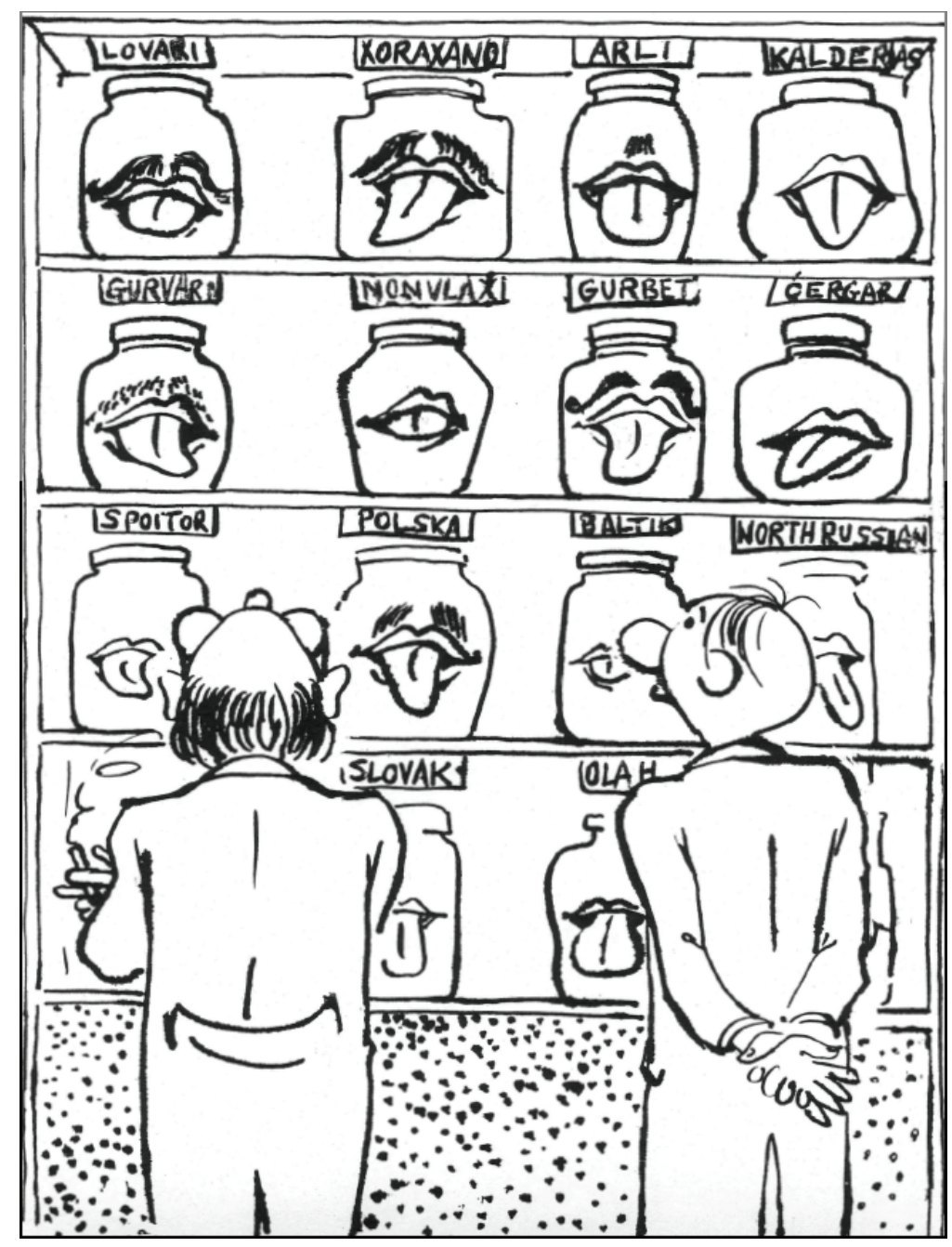




\begin{abstract}
The paper reports how Rromani common spelling arose half a century ago on the territory of Southern Serbia in SFRJ, when young Rroms began to write poetry, under the influence of other minorities and the federal system of plurilinguism. In this context, one Rromani poet from Leskovac, Ismet Jašarević, attempted to write alternatively in his father's and mother's vernacular varieties, but noticed that, although there was a perfect mutual understanding in oral communication between speakers of the two varieties, this intelligibility was lacking as soon as these very varieties were written down. Therefore he tried to find a common writing for both of them. So the question of a cover spelling was set up, with several attempts, mainly in his works, but also in Rašiti's and Gaśi's verses. The solution primarily coined there was then extended to a wider area, including SFR of Macedonia, and subsequently adapted successfully to more vernacular varieties. It the same time, there was a similar attempt of cover spelling in the Ussr, at Leksa Manuš's initiative, who planned an ABC-book in Moscow. On the Yugoslav basis, there was also an ABC-book published in Sarajevo at Svijetlost Publisher and a book "Rromani fonetika thaj lekhipa" printed in Novi Sad for the Montenegrin publisher Pobjeda (both in 1986). The presentation deals also with the role played by the research around the edition of youth creation in answering the questions about the - then still unascertained - unity of Rromani, with the help of dialectometrical methods. In 1990 the 4th Worldwide Rromani Congress passed the Decision about the functioning of the Standard Rromani Alphabet, which entered in used shortly after in Romanian school - with a total of 500.000 Rromani pupils who have benefited of mother tongue and culture classes since then. However, due partly to its isolation, as a consequence of the international Blocade against Yugoslavia, and partly to internal conflicts between uneducated players, who found themselves in positions of stake holders, and various subsequent manipulations, the Common Rromani Spelling is still blocked in Serbia by supporters of Serbian cyrillic and Croatian-type Latin spelling, although both of them are very far from the features of Rromani and their use would cut off Serbian Rroms from the European Rromani community in writing, publishing and informatics' technology - that is to say in most media. It is by now too early to say if this is a well designed plan of massive (and racist) linguistic destruction or just the result of incompetency of organs of power.
\end{abstract}

Keywords: Rromani language teaching; Rromani literary standard; history of standardization; Rroms in Yugoslavia; Rroms in the USSR; Rroms in Romania; oral/ written communication. 


\section{ANNEX I \\ Ten rules for the Elaboration of a Common Rromani Language \\ (from the conclusions of the scientific conference RROMANI \\ LANGUAGE AND CULTURE - Sarajevo 1986) \\ 1) "All spoken Romani dialects are of equal merit and no one dialect} is superior to any other dialect. Nevertheless there is a need for an international standardized dialect which could be used in periodicals and in congresses" (Decision of the First Wold Rromani Congress, London - 1971).

2) Lexico-statistical studies confirm that Rromani vernaculars are not separate languages but rather dialects of one common language. Since Rromani vernaculars are in very close mutual relations, they have a sufficiently broad common basis, which may be used to support the central language.

3) The central language has both spoken and written forms. In written form one uses all means able to stress what is common among the vernaculars and to minimize on paper irrelevant features which differentiate vernaculars and disrupt communication. The tolerance of forms is greater in spoken language, because practice reveals that differences hinder communication to a much lower level.

4) The spelling of the central language aims at reducing in script interdialectal differences in pronunciation but also needs to respect as much as possible the individual characteristics of natural vernaculars. This spelling is a common code of writing the common element, without causing any changes in the language, actually just adapting to it a system of written characters, namely a code of letters. This process is therefore called codification.

5) The items, which can not be reduced through codification to a form in agreement with the general language, should be discarded, replaced or harmonize; this intervention is called normalization and a special commission should be set up for this purpose.

6) Thanks to codification, we all write in the same way various realizations of phonetic units, including when the same is pronounced differently, depending on the given dialect or the position of the given unit in the word, and this consistently. 
For example, both pronunciations [thavo] in a dialect without mutations and [6avo] in a dialect with mutation lead to a common spelling ćhavo, because the grapheme ćh is always pronounced the same way, namely $[\mathrm{gh}]$ in dialects without mutations and [6] in dialect with mutation.

In the same way we write the graphem $\mathbf{g}$ in the word gili, irrespectively of the concrete realizations and everyone pronounces according to his/her habit as [gilji, ǵilji, đilji, džilji, etc.].

7) When these divergences are not consistent and do not concern all words containing the given phonemic unit, we have three cases:

a) in the case of frequent divergences, we will leave both pronunciations [and their written notation], as for example zoralo and zuralo, bister and bistar, or sivel and suvel etc.

b) we may denote as well the difference using accented characters, such as bora and boră, phirel and phirël, śil and śil etc.

c) in the case of limited divergences, the Language Commission will have to decide in each particular case how much they hinder communication, whether two collateral forms may be tolerated or whether one of them has to be marked as non-advisable. This normalization is carried out in cases, where codification is not sufficient to adjust the system of letters to the language, but must partially adapt the language to the common norm.

8) Each postposition (with respectively benefactive/dative, possessive, locative, ablative and comitative meanings) has only one written form, regardless of its pronounciation, since its position and the sandhi rules specific to each vernacular give automatically the correct pronunciation - for example:

\begin{tabular}{|c|c|c|c|c|c|}
\hline & & singular & & pluralмножина & \\
\hline oblique case & & phrales & & phralen & \\
\hline benefactive (goal) & & phralesqe & ke & \begin{tabular}{|l|} 
phralenqe \\
\end{tabular} & ge \\
\hline \multirow[t]{3}{*}{ possession } & masc. sg. & phralesqo(ro) & ko(ro) & phralenqo(ro) & go(ro) \\
\hline & fem. sg. & phralesqi(ri) & ki(ri) & phralenqi(ri) & gi(ri) \\
\hline & plural & phralesqe(re) & ke(re) & phralenqe(re) & ge(re) \\
\hline locative (place) & & phrales $\theta \mathrm{e}$ & te & phralen $\theta \mathrm{e}$ & de \\
\hline ablative (origin) & & phrales $\theta$ ar & $\operatorname{tar}$ & phralen $\theta$ ar & dar \\
\hline $\begin{array}{l}\text { comitative (instr./ } \\
\text { accomp.) }\end{array}$ & & phraleça & $\mathrm{sa}$ & phralença & $\mathrm{ca}$ \\
\hline
\end{tabular}


Each postposition starts with one of the specific postpositional graphemes $\mathbf{q}, \boldsymbol{\theta}$, or $\mathbf{c}$, which performs simultaneously four functions:

a) it covers all phonetic realizations, according to the given vernacular;

b) it indicates the place of the sandhi;

c) it informs about the presence of a postposition and its meaning, making the text easier to read; lable).

d) it indicates the place of the stress (always on the previous syl-

9) For words which are more or less the same in all Rromani vernaculars (such as manuś, ćang, phuv, luludi/luludǐ etc.), the mere rules of codification provide the proper written form.

For words with major differences (such as zukel/rikono, korr/men, nakh/ruthuni, bagal/gilăbel etc.), a specific commission has to examine each lexical case separately and carry out normalization, the main rules being as follows:

a) if all the variants are original Rromani words, all of them may be preserved, as representing cultural richness (synonyms) and probably they will gradually develop between them distinctions in terms of meaning or connotation;

b) if some variants are not of Rromani origin, priority will be given in principle to the genuine Rromani word against the loanwords;

c) if all variants are borrowings and there exists a widely known international word (such as plàno, rakèta, revolùcia etc.), this one will be integrated into Rromani;

d) if there is no such an international word, the Commission will have to create an expression on the basis of the Rromani linguistic material or borrow from European terminology. In certain cases, especially in the field of culture, Indian roots may be used (as for example pustik "book", lekhel or lekhavel "to write" etc.).

10) For all of these principles, only broad practice will decide if they have to be be further improved and developped in order to create a solid and adequate Rromani language.

Similarly practice will show whether this process of unification will be extended until the fusion of the vernaculars into one unique form or 
whether we will still see lengthily all Rromani vernacular develop freely next to each other upon a common basis, along with a strategy of training to mutual understanding. Both options are included in the project presented here.

\section{ANNEX II \\ Decision: "The Rromani alphabet" \\ ("Declaration on a joint Rromani alphabet and its polylectal use" as passed at the 4th Rromani World Congress - Serock-Jadwisin, near \\ Warsaw, in 1990)}

Warsaw, 07 of IV 1990

The Commission for the Standardization of the Rromani Language gathered in Warsaw on the 5th and 6th of April 1990 under the patronage of UNESCO and took the following decisions:

1. written Rromani is one language, with minor variations, and Rroms read it with flexibility, each according to the pronunciation of his/ her own dialect.

2. the Rromani alphabet is specific, based upon the Latin script with some small modifications and we are not supposed to use the alphabet of any other language.

3. one grapheme or diacritic may fulfill only one function.

4. in the standard language, there are 5 (five) vowels: a e i o u; some of them are in lexical variations but this phenomenon does not pertain to phonetics or phonemics.

5. in the standard language there are no centralized vowels; such may be encountered only in texts with dialectal character. They are then indicated by two dots " (ä as Romanian â [or î], Russian $\mathbf{b}$, Polish y, Turkish $\mathbf{\imath}$ etc.), $\ddot{\mathbf{e}}$ as Romanian $\breve{\mathbf{a}}$, Albanian $\ddot{\mathbf{e}}$, Bulgarian $\mathbf{\mathbf { b }}$ etc..) and $\ddot{\mathbf{o}}$ and $\ddot{\mathbf{u}}$ as in the Germanic languages [or in Hungarian]).

6. constricted vowels are not accepted in the standard language.

7. there are no diphthongs with $[\mathrm{w}]$ in the standard language.

8. preyotization is indicated by means of the "ćiriklo": (inflex or caron). 
9. there are no other vowels.

10. there is only one $\mathbf{I}$ in Rromani language and it has two variants according to its position.

11. one distinguishes between $\mathbf{h}$ (laryngeal) and $\mathbf{x}$ (velar).

12. dorsal stops $\mathbf{g}, \mathbf{k}$ and $\mathbf{k h}$ are spelled after the ProtoRromani system and everyone reads them according to his/her own dialect (palatalized or not).

13. aspirated consonants are indicated by means of the grapheme $\mathbf{h}$ : ph, th etc...

14. there is a tendency to keep the opposition between two r's: one simple and one not (pronounced as retroflex, nasal, etc.) in all the dialects, where this opposition does exist. In these dialects it is spelled rr.

15. the principle of postpositions is retained; they indicate the sandhis I, II and III and are characteristic for neo-Indic languages. Their first graphem (archigraphem) is $\mathbf{q}$, ç and $\boldsymbol{\theta}$ (instead of $\mathbf{8}$, which has been rejected from standard spelling).

16. the spirants are written c, ć, ćh (or ch), s, ś, z, ź and $\mathbf{z}$ (or $\mathbf{3}$ ).

17. the symbol $[\mathrm{dz}]$ is rejected since it has no phonemic value.

18. the spirants (affricates) ćh and 3 (3) are pronounced resp. [th] and [d] in the dialects I and II and smooth [6] and [z] in the dialect III. The neutralization between [S] and [6] and between [3] and [3] is not accepted in the standard language.

19. the stress is generally final (oxytonic). Where it is not final, its place is indicated by means of the grave accent (à, è etc.).

20. there are no short and long vowels in opposition. All are medium.

21. when there are two possible constructions (one analytic and the other one synthetic) the synthetic one is preferred.

Warsaw (Jadwisin-Serock) 07. IV. 1990 — signed by S. Balić, R. Djurić, G. Demeter, Ś. Jusuf, M. Heinschink, A. Lewkowicz, I. Danka, R. Gsell, L. Manuś, A. Jòśi, I. Śabàni, S.-K. Thakkar, M. Courthiade, I. Hancock, A. Daróczi, T. Pobożniak, L. Ćerenkov and V. Koptilov (UNESCO special representative). 


\section{AMARI ALFABÈTA $A$ A $B$ b}
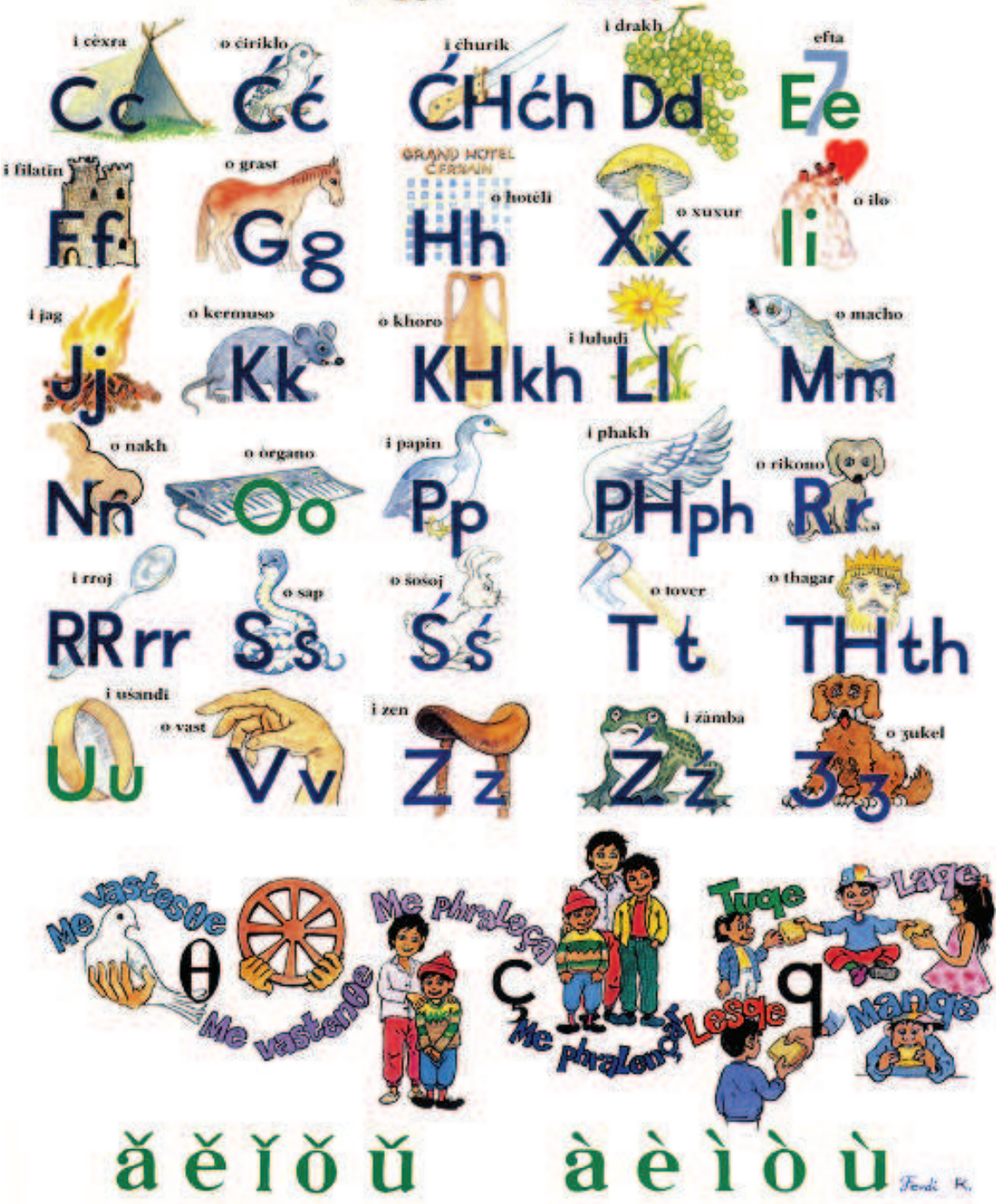


\section{Biographical statement}

DR. MARCEL COURTHIADE has been the Commissioner of the International Rromani Union for language and language rights and professor of Rromani language and culture in the City INALCO Paris-Sorbonne since 1997. He has been acquiring on the ground everyday practice in Balkan languages since 1973 and has researched the development of the Rromani language first in the Balkan Peninsula (he originates from Greece) and then at the European and world wide level. He received his $\mathrm{PhD}$ at the Paris III Sorbonne on the theme "Phonology of Rromani dialects and written diasystem of the Rromani language" (969 pp.). He has published almost 300 scientific papers, of which so far about 80 are on the site www. marcel-online.net. He also works as a co-author and editor for the interactive on line course of Rromani language, literature, history, tradition, linguistics and dialectology, etc ... (www.red-rrom.com - password available on request). He organized a large exhibition "The Rromani language: an Asset for Education and Diversity (56 m length)" in the main hall of the European Council in Strasbourg in 2014 and two years later at the Indian Ministry of Foreign Affairs in New-Delhi. Currently he is involved in preparing the scientific and cultural activities marking the 1000 anniversary of the "Baro Telăripe" (the proto-Rroms" deportation from the city of Kannauj (now in U.P.) at the end of 1018).

E-mail: sr2emc@gmail.com 